\title{
LEGAL ANALYSIS AGAINST SEX GRATIFICATION ON COURT DECISION NUMBER: 87 /PID.SUS /TPK /2013 / PN.BDG
}

\section{ANALISIS HUKUM TERHADAP GRATIFIKASI SEKS PADA PUTUSAN PENGADILAN NOMOR : 87/PID.SUS/TPK/ 2013/PN.BDG}

\author{
Ade Destyani*, Jopie Gilalo,** \\ ade.destyani@unida.ac.id
}

(Diterima pada: 01-07-2018 dan dipublikasikan pada: 30-09-2018)

\begin{abstract}
Gratification in criminal law in Indonesia is a gift in the broad sense of discounts, commissions, interest-free loans, travel tickets, and other facilities as a mode to influence a policy that is contrary to its duties and obligations as a public servant or state administrator. Giving is no exception, including the provision of services in the form of sex. However, in Law Number 20 Year 2001 concerning the Eradication of Corruption, the enforcement of categorized gratification law on difficult law enforcement, as its proof is bound by laws and regulations concerning the law of evidence, therefore this type of corruption is not can use the conventional legal system. The alternative to overcome the limitations of Law Number 31 Year 1999 in conjunction with Law No. 20 of 200 on Corruption Eradication of Gratification of sex law is to fill the legal vacuum by using the authority of judges during the examination of cases in court. Court verdict Number: 87/ PID.SUS /TPK /2013 PN.BDG found the fact that one of the witnesses in the court provided information that the defendant requested sexual services every Thursday or Friday night, but in legal considerations the fact was not considered, it can be used as evidence against the defendant. The authors, judges in giving consideration of the decision need to elaborate, examine and examine more deeply the facts about the sex gratification associated with the explanation of Article $12 \mathrm{~B}$ paragraph 1. For the long term also need to absorb Islamic law as solving the problem of sexual gratification so that found the right solution in legal reform in Indonesia.
\end{abstract}

Keywords: Legal Analysis, Sex Gratification, Law Enforcement

\begin{abstract}
ABSTRAK
Gratifikasi dalam hukum pidana di Indonesia adalah pemberian dalam arti luas berupa diskon, komisi, pinjaman tanpa bunga, tiket perjalanan wisata, dan fasilitas lain nya sebagai modus untuk mempengaruhi suatu kebijakan yang berlawanan dengan tugas dan kewajibannya sebagai pegawai negeri atau penyelenggara negara. Pemberian tersebut tak terkecuali termasuk pemberian layanan berupa seks. Namun dalam Undang-undang Tindak Pidana Korupsi, penegakan hukum gratifikasi terkategori pada penegakan hukum yang sulit, karena pembuktiannya terikat oleh peraturan perundang-undangan tentang hukum pembuktian, karenanya korupsi jenis ini tidak dapat menggunakan sistem hukum konvensional. Alternatif mengatasi keterbatasan Undang-undang Nomor 31 Tahun 1999 jo Undang-undang Nomor 20 Tahun 2001 tentang Pemberantasan Tindak Pidana Korupsi terhadap penegakan hukum gratifikasi seks ialah mengisi kekosongan hukum dengan menggunakan kewenangan hakim pada saat pemeriksaan kasusnya di pengadilan. Putusan pengadilan Nomor :87/PID.SUS/TPK/2013/PN.BDG ditemukan fakta bahwa salah seorang saksi di pengadilan memberikan keterangan bahwa terdakwa meminta
\end{abstract}

\footnotetext{
* Fakultas Hukum-Universitas Djuanda Bogor, Jl.Tol Ciawi No 1, Kotak Pos 35 Bogor 16770

** Fakultas Hukum-Universitas Djuanda Bogor, Jl.Tol Ciawi No 1, Kotak Pos 35 Bogor 16770
} 
layanan seksual setiap kamis atau jumat malam, namun dalam pertimbangan hukum tidak dipertimbangkan, padahal seharusnya keterangan nya dapat dijadikan sebagai alat bukti yang memberatkan terdakwa. Hemat penulis, hakim dalam memberikan pertimbangan putusan perlu mengelaborasi, mengkaji dan meneliti lebih dalam fakta-fakta mengenai gratifikasi seks tersebut dihubungkan dengan penjelasan Pasal 12 B ayat 1 . Untuk jangka panjang pun perlu mengabsorsi hukum islam sebagai pemecahan masalah gratifikasi seks sehingga ditemukan solusi yang tepat dalam pembaharuan hukum di Indonesia.

Kata Kunci : Analisis Hukum, Gratifikasi Seks, Penegakan Hukum

\section{A. Pendahuluan}

Meningkatnya kasus pidana korupsi akan membawa bencana baik pada kehidupan perekonomian nasional juga pada kehidupan berbangsa atau bernegara. Korupsi juga merupakan pelanggaran terhadap hak sosial serta hak ekonomi masyarakat sehingga tindak pidana korupsi tidak lagi dapat digolongkan sebagai kejahatan biasa. ${ }^{1}$

Sebagaimana data terakhir yang disajikan pada laporan tahunan Indonesia Corruption Watch (ICW) disebutkan bahwa pada pada 2017, Indonesia sebagai negara bersih korupsi menempati peringkat yang ke-96, cukup memburuk peringkatnya dibandingkan dengan peringkat di tahun 2016 yang menempati peringkat ke-90, dan jauh berbeda dengan peringkat yang diraih oleh negara tetangga yaitu Singapura di peringkat ke6, Brunei Darussalam di peringkat ke-32 dan Malaysia di peringkat ke-65. ${ }^{2}$ Ini berarti menunjukkan bahwasanya Indonesia masih memasuki peringkat negara rawan korupsi.

\begin{tabular}{|c|c|c|c|}
\hline Indonesia & Poin & Peringkat & Wilayah \\
\hline 2014 & 34 & 107 & \multirow{2}{*}{ Asia } \\
\cline { 1 - 3 } 2015 & 36 & 88 & \multirow{2}{*}{ Pasifik } \\
\hline 2016 & 37 & 90 & \\
\hline
\end{tabular}

\footnotetext{
${ }^{1}$ Widyo Pramono, Pemberantasan Korupsi dan Pidana Lainnya: Sebuah Perspektif Jaksa \& Guru Besar, Kompas Media, Jakarta, 2017, hlm. 54.

2 www.trasparency.org/cpi2017, diunduh dari data tahun 2017 pada tanggal 23 Mei 2018 pukul 12.05 WIB.
}

\begin{tabular}{|r|r|r|r|}
\hline 2017 & 37 & 96 & \\
\hline Sumber: & Reduksi & dari & Transparency \\
\hline
\end{tabular}

\section{Internasional}

Melawan korupsi adalah tanggung jawab setiap manusia, Penanganan negara terhadap pemberantasan korupsi di Indonesia dilaksanakan oleh institusi penegak hukum yang bersinergi. Penindakan koruptor secara tegas yang seharusnya menimbulkan efek positif bagi pemberantasan korupsi, melalui pelaksanaan kewenangan KPK yang demikian besar dan luas, tidak membuat oknum-oknum pejabat negara lainnya "ketakutan" untuk melakukan korupsi. ${ }^{3}$ Suap yang semakin merajalela dan telah menjadi lumrah yang begitu dihargai. Fenomena tersebut memperlihatkan bahwa hukum pidana tidak dapat berbuat banyak dalam menanggulangi korupsi. ${ }^{4}$

Belum lagi modus operandi korupsi semakin berkembang dan bervariasi, khususnya dalam praktek gratifikasi sebagai bagian dari korupsi. KPK telah menerima sebanyak 1.685 laporan, 551 di antaranya dinyatakan milik negara, 37 ditetapkan milik penerima dan 278 laporan masih dalam proses penelaahan. Bila dilihat dari

\footnotetext{
${ }^{3}$ Nur Mauliddar, Mohd. Din, Yanis Rinaldi, Gratifikasi sebagai Tindak Pidana Korupsi terkait Adanya Laporan Penerima Gratifikasi, Kanun Jurnal Ilmu Hukum, Vol.19, No.1, April 2017, hlm. 157.

${ }^{4}$ Susan Rose-Ackerman, Korupsi dan Pemerintahan : Sebab, akibat dan Reformasi, Pustaka Sinar Harapan, Jakarta, 2010, hlm.125.
} 
instansi pelapor, BUMN/BUMD merupakan institusi paling banyak yang melaporkan gratifikasi dengan 667 laporan, diikuti kementerian dengan 447 laporan, dan pemerintah daerah dengan 239 laporan. $^{5}$

\begin{tabular}{|lc|}
\hline STATUS & JUMLAH \\
\hline Milik negara & 604 \\
\hline Milik Penerima & 40 \\
\hline $\begin{array}{l}\text { Sebagian milik } \\
\text { negara }\end{array}$ & 60 \\
\hline Proses & 349 \\
\hline Non SK & 844 \\
\hline Jumlah & 1897 \\
\hline
\end{tabular}

Tabel 1.1 Gratifikasi Berdasarkan Stasus Kepemilikan

Masalah menyeruak sekarang ialah bagaimanakah dengan gratifikasi seks?

Beragamnya jenis kasus gratifikasi ini dib uktikan denganfenomena kemunculan bentuk korupsi baru gratifikasi seks. Bentuk korupsi ini kerap kali disebut dengan korupsi cinta satu malam/korupsi dengan pelayanan seks. Kasus tersebut sebetulnya sudah banyak muncul, namun penjatuhan hukuman nya belum ada yang menerapkan, ada yang banyak menyebutkan bahwa seorang pejabat mendapatkan gratifikasi seks untuk memuluskan suatu proyek pengadaan barang dan jasa, atau gratifikasi seks diberikan terhadap kelancaran penanganan perkara.

Sebagai perbandingan, seperti conto h kasus yang dialami oleh Izedrik Emir Moeis seorang anggota DPR RI terjerat dalam kasus suap proyek PLTU Tarahan, Lampung. Bahwa dalam pemeriksaan saksi yaitu Pirooz Sharafi terdapat keterangan yang menyatakan bahwa Emir

\footnotetext{
${ }^{5}$ https://www.kpk.go.id/id/berita/siaran-pers/4139capaian-dan-kinerja-kpk-di-tahun-2017, diakses pada tanggal 03 Januari 2018 pukul 21.10 WIB.
}

menerima gratifikasi seksual sekitar Tahun 2002 atau 2003 yang pada saat itu mereka serta Fred Perruci bertemu di sebuah Club yang terletak di Paris, lalu kemudian mereka keluar dari Klub tersebut dengan bersama perempuan yang disewa oleh Fred Perruci untuk menghabiskan malam bersama Emir di Paris.

Selanjutnya setelah mengahadapi proses persidangan pada tahun 2014, Emir divonis oleh hakim dengan hukuman penjara selama 3 Tahun dan pidana denda sebesar seratus lima puluh juta rupiah. Majelis hakim yang memeriksa perkara ini menyatakan terdakwa telah melanggar pasal 11 Undang-undang Nomor 31 Tahun 1999 jo Undang-undang Nomor

20 Tahun 2001 tentang Pemberantasan Tindak Pidana Korupsi sebagaimana dakwaan alternatif kedua. ${ }^{6}$

Kasus diatas menjadi timbul pertanyaan apakah gratifikasi seksual dapat dipandang sebagai perbuatan yang dilarang atau tidak, dan dapatkah undangundang Tindak Pidana Korupsi membuktikan dan menjerat pelaku (pemberi dan penerima) gratifikasi? tentunya tak lepas daripada hakim pada lembaga peradilan dalam melaksanakan peranannya untuk melaksanakan sistem pembuktian pada proses persidangan tindak pidana korupsi yang memiliki kebebasan mengeluarkan pendapat tentang perkara yang sedang diperiksa dan memberikan putusan berdasarkan hasil pembuktian Jaksa Penuntut Umun dan pembuktian dari terdakwa/ Penasehat hukum nya yang didukung dengan keyakinan hakim.

Perlunya sikap hakim dalam menjatuhkan putusan mempertimbangakn banyak

hal,

Peran hakim terhadap tindakan modus gratifikasi seks pada keadaan seperti ini sangat diharapkan oleh masyarakat

\footnotetext{
${ }^{6}$ Kade Richa Mulyawati, TESIS : Kebijakan Hukum Terhadap Gratifikasi Seksual dalam Tindak Pidana Korupsi di Indonesia, Universitas Udayana, Denpasar, 2014, hlm. 125.
} 
pencari keadilan. Sebagai pelaksana dari kekuasaan kehakiman, hakim mempunyai kewenangan melakukan penafsiran terhadap peraturan perundangundangan yang berlaku untuk membuktikan terdakwa bersalah atau tidak bersalah dengan memberikan putusan yang seadil-adilnya. ${ }^{7}$

Putusan pengadilan Nomor:

87/PID.SUS/TPK/2013/PN.BDG atas Ter dak-wa Setyabudi Tejocahyono bila

diperhatikan dalam putusan yang dijatuhkan kepada terdakwa tersebut, unsur gratifikasi seksual yang diterima terdakwa seperti yang sempat dikemukakan oleh salah satu saksi yang diperiksa saat penyidikan dan didepan persidangan tidak menjadi pertimbangan hakim dalam menjatuhkan vonis terhadap Terdakwa.

Maka dari itu melihat kasus korupsi bentuk gratifikasi pada putusan tersebut masih ada penegakn hukum terkait gratifikasi seks terkendala dengan aturan perundang-undangan juga terkait pada pembuktiannya.

Berdasarkan latar belakang yang telah penulis uraikan di atas, maka identifikasi masalah dalam penelitian ini adalah :

1. Bagaimana Analisis Hukum terhadap Gratifikasi Seks pada Putusan Pengadilan Nomor: 87/PID.SUS/TPK/2013/PN.BDG ?

2. Bagaimana Analisis Undang-undang Pemberantasan Tindak Pidana Korupsi dengan Hukum Islam sebagai Upaya Pencegahan Gratifikasi Seks dalam Pembaharuan Hukum di Indonesia?

Dalam penelitian ini, metode penelitian deskriptif analisis dengan jenis penelitian yuridis normatif.

\footnotetext{
${ }^{7}$ Nur Mauliddar, Mohd. Din, Yanis Rinaldi, Gratifikasi sebagai Tindak Pidana Korupsi terkait Adanya Laporan Penerima Gratifikasi, Kanun Jurnal Ilmu Hukum, Vol.19, No.1, April 2017, hlm. 157.
}

Metode penelitian ini digunakan untuk membuat uraian secara jelas, sistematis, penelaahan dalam aspek norma, kaidah atau asas-asas hukum dengan menggunakan putusan pengadilan dan bahan pustaka sebagai data dasar penelitian kemudian diperoleh suatu pengetahuan normatif mengenai hubungan hukum terhadap peraturan perundang-undangan dengan permasalahan yang diteliti untuk mendapatkan fakta-fakta yang diinginkan.

\section{B. Gratifikasi Seks Dalam Hukum}

\section{Positif dan Hukum Islam}

\section{Dalam Black's Law Dictionary} gratifikasi juga diartikan sebagai sebuah pemberian (uang dan/atau non-uang) dari satu pihak kepada pihak lainnya denganharapan si pemberi akan memper oleh suatu bantuan atau keuntungan dari pihak yang diberi. Gratifikasi merupakan salah satu penjelmaan perilaku korupsi, yang dengan adanya perilaku korupsi sesungguhnya sistem hukum tidak lagi berdasarkan prinsip keadilan. Hal baru yang menjadi sorotan dalam revisi Undang-undang Pemberantasan Tindak Pidana Korupsi ialah dikenalkannya istilah "gratifikasi" sebagai bagian dari bentuk tindak pidana korupsi. Oleh masyarakat gratifikasi ini lumrah dinamai sebagai kegiatan pemberian sesuatu kepada oran g lain yangdilatarbelakangi sebuah maks ud dengan bertujuan untuk mendatangkan keuntungan bagi nya, juga biasanya dikenal sebagai ucapan terima kasih yang diberikan kepada seseorang karena telah melakukan sesuatu. $^{8}$

\footnotetext{
${ }^{8}$ Fence M. Wantu, et al, Psikologi Anti Korupsi, Pustaka Pelajar, Yogyakarta, 2012, hlm. 68.
} 
Penjelasan Pasal 12 B ayat 1 Undang-undang Nomor 20 Tahun 2001 dalam arti luas gratifikasi disebut sebagai pemberian berupa uang/setara dengan uang, barang, rabat/diskon, pinjaman tanpa bunga, komisi, pengobatan cuma-cuma, tiket perjalanan, perjalanan wisata, fasilitas penginapan, fasilitas lainnya. Gratifikasi tersebut baik yang diterima di dalam negeri maupun di luar negeri dan yang dilakukan dengan menggunakan sarana elektronik maupun tanpa sarana elektronik. $^{9}$

Meskipun aturan yang melarang dalam bentuk apapun telah ada jauh sebelum Undang-undang Pemberantasan Tindak Pidana Korupsi diterbitkan. Larangan tersebut secara rinci sudah diatur pada Keputusan Presiden Nomor 10 Tahun 1974 jo Undang-undang Nomor 47 Tahun 1992 tentang Beberapa Pembatasan Kegiatan Pegawai Negeri Dalam Rangka Pendayagunaan Aparatur Negara dan Kesederhanaan Hidup, khususnya pasal 7 dan 8.

Berikut akan dijelaskan mengenai

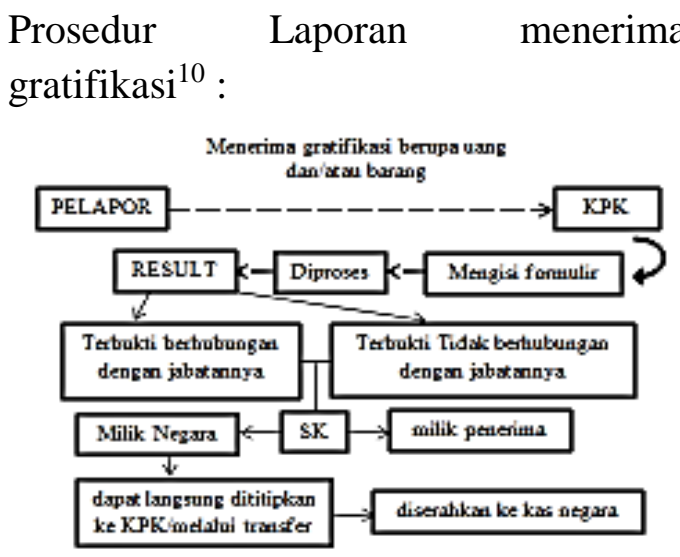

Catatan : KPK tidak bisa memproses apabila gratifikasi tersebut sedang

\footnotetext{
${ }^{9}$ Direktorat Gratifikasi Komisi Pemberantasan Korupsi

${ }^{10}$ Bahan Direktorat Gratifikasi Komisi

Pemberantasan Korupsi.
}

dalam proses penyidikan, penyelidikan, penuntutan.

Prinsip dalam gratifikasi tersirat bahwa dalam menerima pemberian yang diketahui bahwa pemberian itu berhubungan dengan jabatan nya dan bertentangan dengan kewajibannya, maka sebaiknya sejak awal ditolak, ketika tidak dilaporkan bisa jadi nanti ia dikenakan pasal gratifikasi yang dianggap suap, sebab pemberiannya terlarang. bahkan bisa masuk ke dalam pasal suap.

\section{Unsur-unsur Gratifikasi}

Unsur Tindak Pidana Korupsi jenis gratifikasi dilihat dari besarnya gratifikasi, dapat dibedakan menjadi dua.

Pertama, gratifikasi Unsur Tindak Pidana Korupsi "menerima gratifikasi bernilai sepuluh juta rupiah atau lebih" seperti diatur dalam Pasal 12 B ayat (1) huruf a yaitu :

a. Pegawai negeri atau penyelenggara negara;

b. Menerima;

c. Gratifikasi nilainya Rp. 10.000.000,00 (sepuluh juta rupiah) atau lebih;

d. Berhubungan dengan jabatannya dan berlawanan dengan kewajibannya atau tugasnya. ${ }^{11}$

Istilah "seks" secara etimologis, berasal dari bahasa Latin "sexus" kemudian diturunkan menjadi bahasa Perancis Kuno "sexe". Istilah ini merupakan teks bahasa Inggris pertengahan yang bisa dilacak pada periode 1150-1500 M. "Seks" secara

\footnotetext{
${ }^{11}$ Tjandra Sridjaja Pradjonggo, Sifat Melawan Hukum dalam Tindak Pidana Korupsi, Indonesia Lawyer Club, Surabaya, 2010, hlm. 146-147.
} 
leksikal bisa berkedudukan sebagai kata benda (noun), kata sifat (adjective), maupun kata kerja transitif (verb of transitive).Seksual atau seks adalah kegi atan yang berkaitan dengan manipulasi organ kelamin yang lebih khususnya adalah hubungan seksual. ${ }^{12}$

Mengenali sejarah seks para ahli demografi dan psikiater pertama pada abad ke-19, ketika berbicara tentang seksualitas merasa perlu meminta maaf karena menarik perhatian. Kita pun sejah berpuluh-puluh tahun selalu pasang gaya manakala berbicara tentang seks : menentang kemapanan dengan sadar, bersuara dengan lagak subversif. Gagasan tentang seks tidak pernah lebih dikekang daripada zaman itu yang bertujuan mengubah posisinya dalam kehidupan sehari-hari, menggulingkan hukum yang mengaturnya dan pada akhirnya mengubah masa depannya. Menganggap bahwa seks merupakan hal paling penting, harta yang kurang kuat sehingga yang menjadi tokoh pertama yang diseksualkan adalah ibu rumah tangga yang tidak bekerja, remaja lakilaki yang memboroskan masa depannya secara substansial dalam berbagai kenikmatan rahasia, anak-anak penggemar onani. ${ }^{13}$ Sehingga saat ini bagaimana pemegang kekuasaan perlu melembagakan suatu pengetahuan tentang seks. Maka pengendalian seksual akan semakin intensif dan cermat. ${ }^{14}$

Secara terminologis seks adalah sebuah konsep tentang pembedahan jenis kelamin manusia berdasarkan

${ }^{12}$ Anton M. Moeliono, et al, Kamus Besar Bahasa Indonesia, Balai Pustaka, Jakarta, 2008, hlm.1228.

${ }^{13}$ Michel Foucault, Ingin Tahu Sejarah Seksualitas, Yayasan Obor Indonesia, Jakarta, 2008, hlm. 159.

${ }^{14} \mathrm{Ibid}$, hlm. 127. faktor-faktor biologis (sesuatu yang bersifat biologis), seks merujuk pada alat kelamin. $^{15}$ seks adalah nafsu syahwat, yaitu suatu kekuatan pendorong hidup yang biasanya disebut dengan insting/naluri yang dimiliki oleh setiap manusia, baik dimiliki laki-laki maupun perempuan yang mempertemukan mereka guna meneruskan kelanjutan keturunan manusia. ${ }^{16}$

Seks adalah jaringan luas di permukaan tempat rangsangan badaniah, intensifikasi kenikmatan, pembentukan pengetahuan yang saling berkaitan dan seksualitas yang menimbulkan pengertian seks sebagai unsur spekulatif yang perlu bagi cara kerja seksualitas. ${ }^{17}$

Seks dalam arti sempit hanya membedakan secara biologi alat kelamin, organ reproduksi perempuan dan laki-laki. Sementara arti luasnya ialah konsep mengenai bagaimana menjaga kesehatan dan memfungsikan secara optimal organ reproduksi, bagaimana menjalankan fungsi sebagai makhluk sosial. Seks akan menciptakan 2 (dua) aktivitas seksual.

1) Perilaku seksual: menggoda, merayu, bersunyi-sunyi, berbicara dan berpakaian seksi, memperlihatkan sesuatu/ aksi/ grafi yang memuat unsur porno. Perilaku ini akan merangsang hubungan seks yakni kegiatan untuk mendapatkan kesenangan organ seksual.

\footnotetext{
${ }^{15}$ Musdah Mulia, Mengupas Seksualitas, Opus Press, Jakarta, 2015, hlm. 2.

${ }^{16} \mathrm{http}: / / w w w . r e f e r e n s i m a k a l a h . c o m / 2012 / 11 /$ definisi seks-dan-seksualitas.html, diakses pada tanggal 05 Maret 2018 pukul 17.00 WIB.

${ }^{17}$ Loc.Cit, Michel Foucault, Ingin Tahu Sejarah Seksualitas, hlm. 206.
} 
2) Hubungan seksual (kontak seksual) : hubungan badan yang dilakukan oleh laki-laki bersama perempuan ataupun oleh sesama jenis yang meliputi berpegangan tangan, bercumbu, memeluk, melakukan seks anal, seks oral, seks vaginal, mutual masturbasi. $^{18}$

Hukum Islam dengan tegas mengharamkan seorang pegawai menerima hadiah yang ada kaitannya dengan tugas dan jabatannya. Jabatan yang dimaksud adalah kewenangan yang dimiliki pejabat negara atau penyelenggara negara untuk berkontribusi dalam menentukan kepentingan rakyat. Gratifikasi tersebut dalam hukum islam disebut sebagai jarimah risywah (tindak pidana penyuapan).

Dalam hukum pidana islam konsep jarimah terbagi pada 3 kelompok, antara lain sebagai berikut :

1) Jarimah qishos, kejahatan yang dihukum sama sesuai perbuatannya seperti pembunuhan (qotlu). Apabila pembunuhannya berencana maka hukumannya sama-sama dibunuh, dan bila pembunuhan tidak direncakanan dijatuhi hukuman diyat atau denda. Atas hukuman keduanya menyatu atas dua hak yakni haqqullah dan haqquladami.

2) Jarimah hudud (had/batas), artinya hukuman bagi pelaku kejahatan hanya melekat hak Allah dan tidak ada hak manusia untuk menghukumnya. Aturan/larangan dan hukumannya sudah jelas tertera dalam Al-qur'an dan hadist. Yang termasuk dalam pidana ini adalah

\footnotetext{
${ }^{18}$ Ibid, Hlm. 208.
}

mencuri, judi, riba, merampok, mabuk, dan termasuk zina.

3) Jarimah ta'zir, ialah pidana yang perbuatannya dilarang oleh Allah namun hukuman terhadap pelakunya belum ditentukan, dan ini menjadi tanggung jawab ulil amri/pemenritah untuk membuat hukumnya, seperti hukuman penjara, denda, bahkan sampai hukuman mati.

Sedikit menyinggung mengenai perzinahan yakni zina menurut kata berarti fahisyah, yaitu perbuatan keji, dalam istilah ialah hubungan kelamin antara seorang laki-laki dan seorang perempuan yang satu sama lain tidak terikat dalam hubungan perkawinan. Dalam Ensiklopedi Hukum Islam, zina adalah "hubungan seksual di antara seorang laki-laki dengan seorang perempuan yang tidak/ belum diikat dalam perkawinan tanpa disertai unsur keraguan dalam hubungan seksual tersebut. ${ }^{19}$ Allah Berfirman dalam Q.S An-Nur ayat 2 :

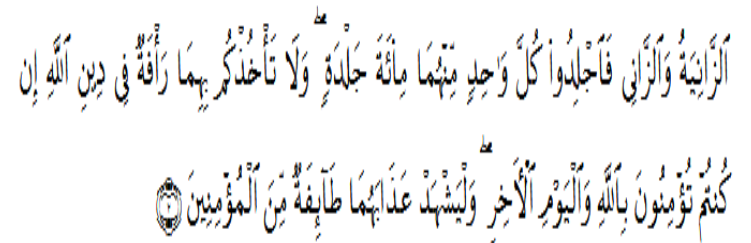

Artinya: Perempuan yang berzina dan laki-laki yang berzina. Maka deralah tiap-tiap seorang dari keduanya seratus kali dera, dan janganlah belas kasihan kepada

keduanya mencegah kamu untu $\mathrm{k}($ menjalankan) agama Allah, jika kamu beriman kepada Allah, dan hari akhirat, dan hendaklah (pelaksanaan) hukuman mereka

\footnotetext{
${ }^{19}$ Abdul Aziz Dahlan, Ensiklopedi Hukum Islam, Jilid 6, Ichtiar Baru Van Hoeven, Jakarta, 1996, hlm. 2026.
} 
disaksikan oleh sekumpulan orang-orang yang beriman".

Berbeda hal dengan zina menurut hukum positif yakni hanya berhubungan kelamin di luar perkawinan yang sah, yang kemudian berlaku hanya untuk untuk mereka yang sudah berada dalam status bersuami atau beristeri. ${ }^{20}$ Pasal 284 KUHP menyebutkan:

1. Dipidana dengan pidana penjara selama-lamanya 9 (sembilan) bulan;

a. Laki-laki yang beristeri berzina sedang diketahuinya, bahwa pasal 27 KUHPerdata berlaku baginya;

b. Perempuan yang bersuami yang berzina.

Secara garis besar dalam menentukan zina ke dalam ruang lingkup ta'zir, perlu diketahui unsurunsur nya, yakni unsur-unsur dasar dan unsur-unsur umum. Adapun unsur-unsur dasar mencakup sabagai berikut :

1. Al-Rukn al-Syar'i (unsur hukum), yaitu ketentuan yang jelas untuk melarang suatu perbuatan yang merupakan kejahatan dan menentukan hukum atasnya. Q.S AlIsra' ayat 32 yang artinya : "Dan janganlah kamu mendekati zina. Sesungguhnya zina itu adalah perbuatan yang keji da merupakan jalan yang buruk."

2. Al-Rukn al-Madi (unsur material), yaitu berupa perbuatan, baik perbuatan aktif maupun perbuatan pasif. Adanya persetubuhan yang dilakukan seorang laki-laki dengan seorang wanita di luar ikatan perkawinan.

3. Al-Rukn al-Adabi (unsur moril), yang meliputi kedewasaan, dapat bertanggungjawab dan dapat dipersalahkan pada diri si pelaku. Pelaku zina adalah mukallaf yang artinya telah baligh dan berakal, yang telah cakap bertindak hukum.

Sementara unsur khusus dari kejahatan berbeda-beda deng berbedanya sifat kejahatan. Inı dibicarakan dalam membahas kejahatan-kejahatan tertentu. Karena itu, satu tindak pidana dapat memiliki unsur yang khusus yang tidak ada pada tindak pidana lainnya. Pada zina unsur khusus ini adalah dilakukannya secara sengaja, sadar dan terhindar dari segala bentuk keraguan, pelaku mengetahui bahwa perbuatan zina itu hukum nya haram. ${ }^{21}$

Landasan tersebut adalah hadist Rasulullah SAW yang diriwayatkan oleh ubadah ibnu Ash-Shamir bahwa Rasulullah SAW bersabda :

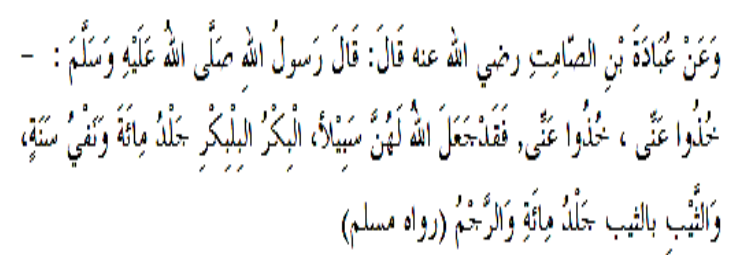

Artinya: dari Ubadah bin Shamit, ia berkata: telah bersabda Rasulullah saw. "Ambillah (hukum) daripada-ku! karena sesungguhnya Allah telah bukakan jalan bagi mereka (perempuan-perempuan yakni Allah telah adakan hukum atas perempuan yang berzina), yaitu, perawan yang berzina dera seratus kali dan pengasingan setahun, dan yang sudah berkawin dengan yang sudah berkawin dera seratus kali dan dirajam". (H.R Muslim).

\footnotetext{
${ }^{20}$ Ahmad Wardi Muslich, Hukum Pidana Islam, Sinar Grafika, Jakarta, 2009, hlm 3.
}

${ }^{21}$ Ibid, hlm. 33. 
Gratifikasi dalam bentuk seksual ini memang belum pernah terjadi sejak jaman Rasulullah SAW, dalam berbagai hadist mengenai gratifikasi atau risywah selalu bermakna pemberian uang dan/ atau barang. Namun menurut hukum pidana Islam dapat dikategorikan sebagai jarimah ta'zir yakni perbuatan yang dilarang dengan jumlah hukumannya tidak terbatas guna memenuhi kemashlahatan umum (masyarakat) dan diserahkan kepada ijtihad penguasa untuk menentukan kadarnya serta melaksanakannya. Sebab membuktikan gratifikasi seks ini tidak semudah membuktikan gratifikasi berupa uang dan/barang yang terlihat jelas fisik nya bila bukan karena tertangkap tangan. ${ }^{22}$

\section{Putusan Pengadilan Nomor :87/PID.SUS/TPK/2013/PN. BDG Atas Terdakwa Setyabudi Tejocahyono}

\section{Posisi Kasus}

Ada dua indikator perbuatan Terdakwa. Pertama, Terdakwa bersama H. Ramlan Comel dan Djojo Djohari merupakan Hakim yang memeriksa, mengadili, dan memutus Perkara Tipikor Penyimpangan Bantuan Sosial (Bansos) Kota Bandung Tahun Anggaran 2009-2010 yang ditetapkan oleh Singgih Budi Prakoso selaku Ketua PN Bandung. Perkara tipikor tersebut melibatkan para terdakwa antara lain Uus Ruslan, Yanos Septiadi, Luthfah Barkah, Firman Himawan, Ahmad Mulyana, Rochman, dan Havid Kurnia.

Terdakwa secara aktif terdakwa melakukan beberapa perbuatan yang ada

\footnotetext{
${ }^{22}$ H.M. Nurul Irfan, Gratifikasi dan Kriminalitas Seksual dalam Hukum Pidana Islam, Amzah, Jakarta, 2014, hlm. 57.
}

hubungannya sedemikian rupa sehingga dipandang sebagai perbuatan berlanjut, menerima hadiah, atau janji yang menyalahgunakan kewenangannya untuk mempengaruhi putusan perkara yang diserahkan padanya. Toto Hutagalung sebagai orang kepercayaan Walikota Bandung yang memiliki kedekatan dengan Dada Rosada (Walikota Bandung) menjadi perantara Dada Rosada, Edi Siswadi (Sekda Pemkot Bandung) dan Herry Nurhayat kepada Terdakwa untuk berbuat sesuatu yakni menjatuhkan putusan yang tidak melibatkan ketiga orang tersebut serta meringankan hukuman kepada terdakwa masing-masing atas perkara korupsi Bansos Kota Bandung.

Dalam perkara diatas Terdakwa sejak 4 mei 2012 pada waktu-waktu lain dalam tahun 2012 berangsur-angsur meminta untuk diberikan uang sejumlah Rp. 1.810.000.000.- dan USD 160.000 ; barang berupa perabotan rumah dinas Wakil Keua PN Bandung ; serta fasilitas hiburan di Venetia Spa, Launge \& Karaoke yang selalu bersama Toto Hutagalung dan H.Ramlan Comel sebanyak 12 kali, setiap kali nya mengeluarkan uang Rp. 25.000.000,yang berasal dari Dada Rosada dan Herry Nurhayat. Kemudian dijatuhkannya lah putusan perkara tersebut sesuai dengan yang diinginkan. Atas dasar putusan itu JPU mengajukan upaya Hukum Banding pada Pengadilan Tinggi (PT) Bandung.

Kedua, sebelum upaya hukum Banding akan diajukan JPU ke PT Bandung, Terdakwa menjanjikan akan membantu pengurusan perkara tersebut melalui Sareh Wiyono selaku Ketua PT Bandung. Untuk membahasnya Terdakwa bertemu dengan Dada Rosada, Edi Siswadi , Herry Nurhayat 
dan Toto Hutagalung di kediaman Toto Hutagalung, yang mana dalam pertemuan tersebut Dada Rosada meminta agar PT Bandung menguatkan putusan PN Bandung.

Setelah beberapa kali Terdakwa menemui Sareh Wiyono untuk memastikan siapa saja Majelis Hakim yang ditetapkan untuk menangani perkara tersebut, $\mathrm{CH}$ Kristi Purnamiwulan (Plt.Ketua PT Bandung) atas arahan Sareh Wiyono menetapkan Wiwik Widijastuti Sutowo, Pasti Serefina Sinaga, dan Fontian Munzil sebagai Majelis hakim yang akan menangani perkara nya.

Kemudian Yang terlibat menikmati penerimaan Aliran-aliran dana tersebut antara lain, $\mathrm{CH}$. Kristi Purnamiwulan (Perantara penerimaan uang di wilayah PT Bandung kepada hakim-hakim), Pasti Serefina (karena ditawarkan bantuan dari Dada Rosada agar Hotel Bumi Asih miliknya dapat ditingkatkan menjadi hotel bintang tiga), Fontian Munzil, yang keempat orang tersebut mendapatkan Rp. 1.000.000.000,- secara bertahap, dan Terdakwa yang kembali juga menerima imbalan uang secara bertahap dengan jumlah Rp. 1.145.000.000,- beserta fasilitas hiburan di Venetian Spa, Lounge \& Karaoke juga hiburan organ tunggal pada saat acara perpisahan alih tugas Terdakwa sehubungan acara alih tugas nya sebagai Hakim PT Padang.

Terdakwa setelah menghubungi para pihak di Pengadilan Tinggi Bandung guna pengurusan banding perkara tersebut sejak akhir Januari 2013 s/d Maret 2013 beberapa kali, seusai sholat jum'at Asep Triana menyerahkan sisa dana imbalan sebesar Rp. 150.000.000,- yang dibungkus dengan kertas koran dan disimpan di dalam tas warna hijau atas perintah Toto Hutagalung kepada Terdakwa di Kantor PN Bandung, Asep Triana bersama Terdakwa ditangkap Petugas Komisi Pemberantasan Korupsi.

\section{Dakwaan Penuntut Umum}

Sebagaimana posisi kasus diatas maka Jaksa Penuntut Umum mengajukan terdakwa ke persidangan telah melakukan perbuatan Pidana dengan dakwaan sebagai berikut :

\section{KESATU}

PRIMAIR

Pasal 12 c Undang-undang Nomor 31 Tahun 1999 jo Undang-undang Nomor 20 Tahun 2001 tentang Pemberantasan Tindak Pidana Korupsi jo pasal 64 ayat (1) KUHP jo pasal 55 ayat (1) ke-1 KUHP.

\section{SUBSIDAIR}

Pasal 6 ayat (2) jo pasal 6 ayat (1) huruf a Undang-undang Nomor 31 Tahun 1999 jo Undang-undang Nomor 20 Tahun 2001 tentang Pemberantasan Tindak Pidana Korupsi jo pasal 64 ayat (1) KUHP jo pasal 55 ayat (1) ke-1 KUHP.

\section{DAN KEDUA} PRIMAIR

Pasal 6 ayat (1) huruf a Undang-undang Nomor 31 Tahun 1999 jo Undangundang Nomor 20 Tahun 2001 tentang Pemberantasan Tindak Pidana Korupsi jo pasal 64 ayat (1) KUHP jo pasal 55 ayat (1) ke-1 KUHP.

SUBSIDAIR

Pasal 5 ayat (1) huruf a Undang-undang Nomor 31 Tahun 1999 jo Undangundang Nomor 20 Tahun 2001 tentang Pemberantasan Tindak Pidana Korupsi 
jo pasal 64 ayat (1) KUHP jo pasal 55 ayat (1) ke-1 KUHP.

\section{DAN KETIGA}

PRIMAIR

Pertama : Pasal 12 huruf a Undangundang Nomor 31 Tahun 1999 jo Undang-undang Nomor 20 Tahun 2001 tentang Pemberantasan Tindak Pidana Korupsi jo pasal 64 ayat (1) KUHP.

a t a u

Kedua : Pasal 12 huruf b Undangundang Nomor 31 Tahun 1999 jo Undang-undang Nomor 20 Tahun 2001 tentang Pemberantasan Tindak Pidana Korupsi jo pasal 64 ayat (1) KUHP.

SUBSIDAIR

Pertama : Pasal 5 ayat (2) jo pasal 5 ayat (1) huruf a Undang-undang Nomor 31 Tahun 1999 jo Undang-undang Nomor 20 Tahun 2001 tentang Pemberantasan Tindak Pidana Korupsi jo pasal 64 ayat (1) KUHP.

Kedua : Pasal 5 ayat (2) jo pasal 5 ayat (1) huruf b Undang-undang Nomor 31 Tahun 1999 jo Undang-undang Nomor 20 Tahun 2001 tentang Pemberantasan Tindak Pidana Korupsi jo pasal 64 ayat (1) KUHP.

\section{Putusan Pengadilan}

a. Menyatakan Terdakwa terbukti secara sah dan meyakinkan bersalah melakukan tindak pidana "korupsi secara bersama-sama dan berlanjut";

b. Menjatuhkan pidana terhadap terdakwa berupa pidana penjara selama 12 tahun dikurangi selama terdakwa berada dalam tahanan dan pidana denda sebesar Rp. 200.000.000,- subsidair 3 bulan kurungan, dengan perintah supaya terdakwa ditahan; c. Menyatakan bahwa pemblokiran terhadap rekening atas nama Terdakwa, yaitu rekening BRI No. 3548-01-018015-53-7 dicabut dan dibuka kembali;

d. Menetapkan agar terdakwa membayar biaya perkara sebesar Rp. 10.000,-

Unsur-unsur yang terpenuhi pada tindak pidana korupsi dalam putusan pengadilan Nomor: 87/ PID.SUS/TPK/2013/ PN.BDG antara lain: Ad. 1. Unsur "hakim, Ad.2. unsur "menerima hadiah atau janji", Ad.3. Unsur "Padahal diketahui atau patut diduga bahwa hadiah atau janji tersebut diberikan untuk mempengaruhi putusan perkara yang diserahkan kepadanya untuk diadili", Ad.4. Unsur Perbuatan Berlanjut

\section{Pertimbangan Hukum terhadap Gratifikasi Seks pada Putusan Pengadilan Nomor : 87/PID.SUS/ TPK/2013/PN.BDG}

Menimbang, bahwa dari hasil pemeriksaan di depan persidangan dengan berdasarkan keterangan saksisaksi maupun keterangan terdakwa diatas serta dihubungkan dengan barang bukti yang diajukan dalam perkara ini maka telah didapatkan fakta-fakta sebagai berikut :

- Bahwa benar, bulan April 2012 Pengadilan Negeri Bandung telah menerima pelimpahan lima berkas perkara Penyimpangan Dana Bansos Pemkot Bandung TA 2009 s/d 2010 atas nama Rochman, Firman Himawan, Luthfah Barkah, Yanos Septiadi dan Uus Ruslan. 
-Bahwa benar, pada sekitar bulan Mei 2012 terdakwa bertemu dengan saksi Toto Hutagalung dan menyampaikan pesan bahwa dirinya yang akan menangani perkara Penyimpangan Dana Bansos Pemkot Bandung dan bersedia untuk membantu dalam putusannya tidak akan mempertimbangkan keterlibatan saksi Dada Rosada, saksi Edi Siswadi maupun saksi Herry Nurhayat dalam perkara dimaksud dengan minta disediakan sejumlah uang serta fasilitas hiburan untuk pengurusannya;

Menimbang dalam keterangan Saksi Toto Hutagalung Nomor 39, pada bulan mei 2012 bertempat di Venetia Spa Lounge \& Karaoke Komplek Ruko Hypersquare Bandungterdakwa memperkenalkan Ramlan Comel sebagai salah satu Hakim Anggota Majelis yang menangani perkara tersebut kepada saksi yang kemudian dilanjutkan dengan acara hiburan yang difasilitasi oleh saksi sekitar 12 kali dan setiap kali nya mengeluarkan biaya pasti diatas Rp. 25 juta dimana uang tersebut saksi peroleh dari Sdr. Dada Rosada dan Sdr. Herry Nurhayat;

- Bahwa terhadap acara hiburan di Venetian Spa tersebut, seingat saksi setelah perkara Bansos Pemkot diputus di PN Bandung, yang kemudian Terdakwa menghubungi saksi "ayo bang, hiburan, pusing", dan ketempat Venetian tersebut atas permintaan Terdakwa, karena saksi mengaku orang lapangan sebenarnya tidak berminat ditempat tersebut dengan meminta jatah layanan tersebut pada setiap kamis atau jumat "Saya ini orang lapangan tapi untuk urusan hiburan ternyata Pak Setyabudi lebih ganas daripada saya". Saat dalam penjelasan kepada penyidik pun Toto Hutagalung mengatakan demikian.

- Bahwa benar pada tanggal 17 Februari 2013 terdakwa menghubungi saksi Toto Hutagalung yang pada intinya mengatakan agar pengurusan perkara tersebut dalam tingkat banding tersebut dilakukan melalui "satu pintu" karena akan diurus melalui saksi $\mathrm{CH}$. Kristi Purnamiwulan dan untuk kepentingan tersebut terdakwa meminta disediakan dana sebesar Rp. 1.500.000.000,-

\section{Analisis Hukum Terhadap Gratifikasi Seks Pada Putusan Pengadilan Nomor: 87/PID.SUS/TPK/2013/PN.BDG}

Kejahatan yang dilakukan terdakwa adalah beberapa perbuatan yang tergolong sejenis yaitu menerima hadiah atau janji yang diberikan untuk mempengaruhi putusan perkara yang diserahkan kepadanya untuk diadili dengan dilakukan secara berturut-turut. Yang mana menurut ajaran perbuatan berlanjut (voortgezette handeling) pasal 64 ayat (1) mempunyai tiga syarat, antara lain 1) adanya suatu niat; 2) perbuatannya sejenis; dan 3) waktunya tidak terlalu lama dan masuk ke dalam kategori suap Pasal 12 a Undangundang No 31 Tahun 1999 jo Undangundang Nomor 20 Tahun 2001 tentang Pemberantasan Tindak Pidana Korupsi.

Terdakwa secara sah dan meyakinkan melanggar pasal 6 ayat (1) huruf a sesuai dakwaan primer kesatu; pasal 6 ayat (1) huruf a sesuai dakwaan primer kedua; dan pasal 5 ayat (1) UU No 31/1999 sebagaimana yang diubah dengan UU 20/2001 tentang Pemberantasan Tindak Pidana Korupsi jo pasal 64 ayat (1) jo pasal 55 ayat (1) kesatu KUHPidana. 
Pada paparan kasus posisi terdakwa, yang diharapkan oleh pemberi gratifikasi terhadap nya adalah untuk tidak mempertimbangkan keterlibatan saksi Dada Rosada, saksi Edi Siswadi maupun saksi Herry Nurhayat serta meringankan hukuman kepada terdakwa masing-masing dalam putusannya atas perkara korupsi Bansos Kota Bandung dengan meminta disediakan sejumlah uang serta fasilitas hiburan untuk pengurusannya.

Fakta-fakta di persidangan menunjukkan bahwa terdakwa secara aktif memobilisasi para pihak, dimulai dari menjanjikan sesuatu, meminta atas kesadarannya sehingga perbuatan terdakwa terkategori sebagai perbuatan amoral dan agama melarangnya yang bertentangan dengan visi dan misi Mahkamah Agung Republik Indonesia sebagai upaya pemulihan citra menuju Peradilan yang Agung sekaligus menciderai nama baik lembaga peradilan. Padahal ia mengetahui Pasal 5 angka 4 Undang-undang Nomor 28 Tahun 1999 tentang Penyelenggaraan Negara yang Bersih dan Bebas dari Korupsi, Kolusi, dan Nepotisme.

Dengan hakim memutuskan hukuman terhadap terdakwa penulis melihat bahwa yang menjadi masalah nya dari putusan Nomor: 87/PID.SUS/ TPK/2013/PN.BDG, penekanan nya ada pada persoalan dugaan gratifikasi seksual dalam serangkaian perbuatan yang dilakukan Terdakwa selama itu. Yang mana tidak terurai sama sekali adanya praktek gratifikasi seksual dalam dakwaan dan putusan, tidak dibahas mendalam apakah ini tidak menjadi fakta dipersidangan atau karena memang tidak dikejar. Namun sempat disinggung oleh keterangan saksi Toto Hutagalung di pengadilan yang sebelumnya oleh Toto Hutagalung dalam Pemeriksaan BAP dinyatakan benar.

Apa yang dikatakan saksi Toto Hutagalung dibawah sumpah pada persidangan, ia mengatakan "Sekali karaoke menghabiskan uang Rp. 25 juta, hiburan karaoke dengan menggunakan pemandu lagu dan juga booking hiburan yang lain-lain dan digelar setiap Jumat malam. "Saya ini orang lapangan tapi untuk urusan hiburan ternyata Pak Terdakwa lebih ganas daripada saya", begitu kata saksi Toto Hutagalung.

Sama hal nya dalam putusan perkara atas nama Izedrik Emir Moeis, pada pemeriksaan saksi yaitu Pirooz Sharafi dalam berita acara penyidikan terdapat keterangan yang menyatakan selama jangka waktu Tahun 2002 atau 2003 setidaknya 3 kali bertemu dengan Izedrik dan Pihak Alstom yang pada saat itu mereka serta Fred Perruci bertemu di sebuah Club yang terletak di Paris, lalu kemudian mereka keluar dari Klub tersebut dengan bersama tiga pekerja seks, satu untuk masing-masing. Kemudian Fred Perruci membayar bar untuk mendapatkan pekerja seks tersebut dan menginap di Paris. Namun ini sama sekali tidak menjadi pertimbangan hakim dengan penelusuran yang berlanjut. ${ }^{23}$

Kemudian alat bukti dalam konteks kasus ini yang pertama adalah saksi, minimal saksi harus bisa menceritakan kronologi kejadiannya, dan jaksa hanya bisa membuktikan sebatas itu. Dalam putusan yang terurai dikupas habis adalah penerimaan dalam bentuk uang, di persidangan hanya disinggung pada bagian terkecil dan tidak terurai. Namun seharusnya singgungan dari keterangan ini bisa menjadi petunjuk awal untuk melakukan penelusuran lebih mendalam terhadap gratifikasi seks. Karena keterangan saksi Toto Hutagalung menyatakan pernah berkaraoke selama 12 kali dan setiap kalinya mengeluarkan Rp. 25 juta, mengingat perbuatan ini menurut penulis lebih tak bermoral daripada penerimaan hadiah berupa uang/barang.

\footnotetext{
${ }^{23}$ Putusan Pengadilan Nomor : 66/PID.SUS/TPK/ 2013/PN.JKT.PST.
} 
Ada beberapa catatan yang cukup menjadi perhatian penulis dalam putusan tersebut, sehingga diperlukan suatu akses untuk dapat menjerat pelaku (pemberi dan penerima) gratifikasi seks. Penulis meyakini bahwa makna melakukan seks itu harus terbukti secara jelas masuknya alat kelamin laki-laki dan perempuan, sehingga sudah masuk ke dalam kamar yang sama berdua dengan tidak ada orang lain saja belum tentu dikatakan ia menerima/ menikmati pemberian layanan $\mathrm{S}$ tersebut. Sebagaimana definisi seks itu sendiri telah dijelaskan pada BAB II, menurut Musdah dalam bukunya seks merupakan konsep tentang pembedahan jenis kelamin manusia berdasarkan faktorfaktor biologis (sesuatu yang bersifat biologis), seks merujuk pada alat kelamin. Pun Michael Foucault mendefinisikan seks adalah jaringan luas di permukaan tempat rangsangan badaniah, intensifikasi kenikmatan, pembentukan pengetahuan yang saling berkaitan dan seksualitas yang menimbulkan pengertian seks sebagai unsur spekulatif yang perlu bagi cara kerja seksualitas.

Jadi dari kedua definisi tersebut penulis berpendapat bahwa seks adalah perbuatan aktif maupun pastif atas hubungan biologis antara laki-laki dan perempuan yang dilakukan secara langsung berhubungan dengan alat kelamin.

Hal ini menunjukan bahwa betapa sulitnya untuk membuktikan praktek gratifikasi seks. Namun hal itu bukanlah penghambat untuk membuktikan adanya praktek gratifikasi seks. Bahwa akhirnya putusan tersebut adalah berdasarkan keyakinan hakim saja, dan tidak mempertimbangan putusannya berdasarkan fakta atau bukti secara utuh yang disampaikan didepan pengadilan. Sebab ada kekosongan hukum di dalam nya, bahkan Undang-undang Pemberantasan Tindak Pidana Korupsi sendiri pun tidak nampak membunyikan secara eksplisit pengaturan mengenai gratifikasi seks.

Kemudian yang perlu menjadi catatan dalam kondisi yang ada sekarang sekalipun pengikut positivistik mengatakan makna nya terbuka dan luas, sehingga gratifikasi dalam bentuk layanan seks sudah tersirat dalam definisi tersebut, namun ketika kembali lagi menilik Undang-undang Nomor 31 Tahun 1999 jo Undang-undang Undangundang Nomor 20 Tahun 2001 tentang Pemberantasan Tindak Pidana Korupsi, gratifikasi sendiri memiliki ketentuan untuk melakukan pembalikan beban pembuktian. Yakni mengkontifisir pemberian gratifikasi seks ke dalam nominal, segala pemberian nya dapat dihitung dengan uang.

Pemberian gratifikasi dalam bentuk uang ataupun barang selalu teridentifikasi. Apabila penerima ragu atas penerimaan hadiah tersebut berhubungan atau tidak dengan jabatannya dan takut apabila dikatakan korupsi maka harus melapor kepada KPK maksimal 30 hari kerja. Apakah dengan adanya penerimaan gratifikasi seks ini pembalikan beban pembuktian dapat diterapkan? Dan apakah seks bisa selalu dihitung atau bahkan dikonversi dengan uang?. Penulis mengamati dirasa tidak cocok untuk kasus yang seperti ini.

Berdasarkan hasil wawancara ahli pada Komisi Pemberantasan Korupsi sebagaimana telah dijelaskan pada BAB III. Penulis akan mencoba berikan gambaran tipe pemberi menjadi 2 (dua), tipe yang pertama yaitu pemberi nya bukan sekaligus menjadi objek, ia hanya membayar pelayanan hotel/cafe/klub/ lokasi tertentu yang menjadi tempat untuk berbuatnya,kemudian ia membayar mucikari/pekerja seks/lady escort, yang dapat dibuktikan ialah pemberian entertainment nya, ketika ia dibayarkan misalnya masuk ke hotel tertentu kemudian dikonversi ke dalam rupiah; yang kedua adalah pemberi sekaligus sebagai pelaku pemberi 
layanan seksual. Mungkin untuk membuktikan adanya praktek gtafikasi seks, bukti-bukti tersebut masih bisa dikonversikan dengan uang, Yang sulit ialah jika pemberi nya adalah ia sendiri yang berlaku sebagai pelayan seksual. Di Indonesia ini tentu Bahaya dan kerugian bagi negara bisa jadi sama besarnya, apabila terbukti menyelewengkan kekuasaan nya hanya dengan seks tapi tidak dapat dijerat dan tidak terbukti menerima hadiah berupa uang, bukan berarti menjadi tidak ada tindak pidana korupsi.

menguatkan, sebab penulis sendiri tidak setuju karna itu merupakan hal yang diyakini umat islam yakni perkara-perkara yang positif. Jadi apabila menggunakan alasan tersebut agar dijadikan salah satu dasar untuk

Kelemahan lainnya adalah hakim terbatas kepada dakwaan dan tuntutan jaksa, oleh karna itu maka hakim pun harus mengharapkan unsur gratifikasi seks ada dalam satu bagian dari dakwaan sebab pola pikir jaksa sendiri bersifat positivistik, hanya melihat apa yang ditulis kemudian ini akan membawa dampak kesulitannya bagi hakim dalam membuat pertimbangannya ke dalam amar putusan. Dalam amar tidak akan bisa dipidana karena tidak ada dalam dakwaan, sehingga penulis sebenarnya berharap dengan menginterpretasikan secara luas pasal 12 B akan memberikan ruang bagi jaksa memasukkan unsur gratifikasi seks dalam dakwaan. Akan tetapi tidak menutup kemungkinan bisa menjadi hal-hal yang memberatkan untuk memperkuat tindak pidana korupsi sebagai pembuktian tambahan apabila terbukti dan apabila tidak ada dalam dakwaan jaksa, kedepannya hakim dapat membuat norma hukum yang baru. Hakim diperbolehkan menemukan hukum namun ada sesuatu yang disinggung dalam dakwaan dan tuntutan".
E. Analisis Pendekatan UU

Pemberantasan Tindak Pidana

Korupsi Dengan Hukum Islam Terhadap Gratifikasi Seks Sebagai Upaya Pencegahan Dalam Pembaharuan Hukum Di Indonesia

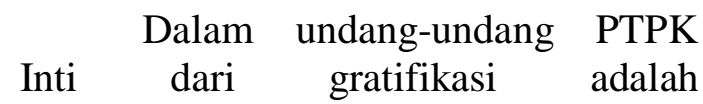
menggerakkan penyelenggara negara untuk berbuat atau tidak berbuat secara melawan hukum suatu perbuatan yang menguntungkan. Sehingga unsur terpenting adalah soal kewenangan penyelenggara negara yang bisa digerakkan oleh pemberi gratifikasi termasuk gratifiksi seks agar digunakan bagi keuntungan pemberi gratifikasi, maka tafsir gratifikasi termasuk seks, itu dengan menafsirkan secara luas bagi penulis adalah wajar untuk masuk ke dalam bagian tindak pidana korupsi.

Maksud dari perbuatan tersebut adalah supaya tersamarkan perbuatannya menjadi lebih gelap bahwa pelaku sebenarnya meminta fasilitas sehingga karena menurut anggapan nya undang-undang Pemberantasan Tindak Pidana Korupsi tidak mengatakan hal itu, ketika ia hobi dengan seks, jadi diberilah fasilitas seks. Maka hal tersebut dapat menjadi bagian dari hal-hal yang memberatkan suatu tindak pidana, sebab ada maksud untuk menutupi perbuatan suap. Tetapi di Indonesia belum timbul kasus yang sampai terungkap secara terang benderang.

seks terjadi karena ketentuan perundang-undangan tidak mengatur bunyi dalam pasal nya, pada akhirnya terdapat kekosongan hukum dalam undang-undang. Kekosongan hukum dapat terjadi karena hal-hal atau keadaan yang terjadi belum diatur dalam suatu peraturan perundangundangan, atau sekalipun namun tidak 
jelas atau bahkan tidak lengkap. Selaras dengan yang dinyatakan oleh Pameo bahwa "terbentuknya suatu peraturan perundang-undangan senantiasa tertinggal atau terbelakang dibandingkan dengan kejadian-kejadian dalam perkembangan masyarakat". ${ }^{24}$

Kemudian masalahnya dalam hukum pembuktian di Indonesia gratifikasi terikat pada sistem pembalikan beban pembuktian, yang tidak mungkin diterapkan pada praktek gratifikasi seks di Indonesia, hal ini tidak bisa dibiarkan terus terjadi. Tentunya analisis ini akan menyulitkan ketika tindak pidana ini dibuktikan, terutama menghubungkan antara perbuatan gratifikasi dengan timbulnya akibat yang dilarang, namun tak berarti nihil cara pembuktiannya.

Menurut penulis saat ini, ketika undang-undang Pemberantasan Tindak Pidana Korupsi belum membunyikan dan mengatur dengan sempurna pengaturan gratifikasi seks, apabila masalah ini timbul kembali, maka dengan menggunakan penafsiran secara ekstensif dirasa cocok, yang menjadi tolak ukurnya adalah apabila pemberian berupa jasa pelayanan seksual ini telah memenuhi dua unsur yakni "....berhubungan dengan jabatannya" dan "...berlawanan dengan kewajiban atau tugasnya". Sebab tidak dapat dipungkiri kedua unsur tersebut merupakan unsur integral yang harus melekat dalam perbuatan yang digolongkan sebagai tindak pidana gratifikasi. Oleh sebab pada undangundang Pemberantasan Tindak Pidana Korupsi gratifikasi seks tidak mengatur secara jelas, maka penafsiran ini dapat digunakan pada saat hakim menilai ternyata peristiwa hukum yang terjadi tidak didapatkan ketentuan hukumnya secara jelas dengan tetap harus melakukan pemeriksaan secara lengkap

\footnotetext{
${ }^{24}$ Henry Arianto, Hukum Responsif dan Penegakan Hukum Di Indonesia.
}

terhadap perkara yang sedang ditangani. Selain penafsiran ekstensif, penafsiran komparatif yakni penafsiran undangundang yang sifatnya idealis dengan melakukan peninjauan pada norma lain, dalam hal ini ialah norma agama, karena gratifikasi seks tak lepas dari unsur melakukan hubungan biologis antara laki-laki dengan perempuan bahkan bisa dengan sesama jenis, jika dilakukan diluar perkawinan yang sah dan tidak dibenarkan, ketika satu sama lain diam, merasa diuntungkan dengan perbuatannya dan secara sukarela melakukannya, lantas apakah ini bukan suatu kesulitan dalam membuktikan perbuatan seks di luar perkawinan?. Kasus ini tentu tidak dapat dipidana jika mengandalkan hukum positif yang berlaku saat ini.

Sebagaimana konsep seks menyatakan bahwa zina hanya termasuk ke dalam salah satu hubungan seksual, selain daripada zina masih banyak hubungan seksual yang pasti terjadi dalam praktek gratifikasi. Batasan terhadap perbuatan seks yang tidak termasuk ke dalam perbuatan zina terdapat dalam Q.S Al-Isra' ayat 32. Berdasarkan ayat tersebut dan pada unsur dasar dan unsur khusus dalam hukum pidana islam dapat menentukan apa saja yang termasuk ke dalam aktivitas seksual sebagai perbuatan jarimah ta'zir, maka penentuan tentang aktivitas seksual (perilaku seks dan perbuatan seks) dalam ruang lingkup ini dapat dikatakan sudah terindikasi dan tergolong ke dalam perbuatan maksiat/kejahatan yang patut dilarang dan dapat ditentukan hukumannya bagi pelaku perbuatan tersebut dengan akibat hukum berupa ancaman sanksi yang telah dilegitimasi oleh syara' (hukum islam). Hal ini juga diperkuat oleh Q.S Al-An'am ayat 120 yang artinya :

"dan tinggalkanlah dosa yang terlihat atau yang tersembunyi, sungguh orang-orang yang mengerjakan 
perbuatan dosa kelak akan diberi balasan sesuai dengan apa yang mereka kerjakan".

Dengan melihat kacamata hukum progresif, seperti perjuangan panjang serta analisis yang mendalam yang telah dilakukan oleh Hakim Bismar Siregar, dimana menafsirkan kehormatan perempuan sebagai barang, sehingga ketika ada laki-laki menjanjikan pernikahan namun sebelum menikah meminta seks, kemudian ingkar janji tidak menikahinya supaya laki-laki tersebut dapat dihukum dianggap sebagai penipuan, sebab menggerakkan orang untuk menyerahkan sesuatu barang. ${ }^{25}$ Meski pada upaya hukum kasasi di Mahkamah Agung memang dibatalkan, karena dianggap merusak sistem, apa yang dimaksud dengan hakhak kebendaan, namun usaha itulah yang patut untuk diapresiasi karena ia memaksimalkan kewenangannya demi keadilan. Ia menganggap itulah keadilan yang digagas oleh Satjipto Raharjo, menjadi soal lain terlepas dari berubahnya sistem hukum dan terindikasi adanya tindak pidana baru pada kasus tersebut.

Penjahat akan berada satu langkah di depan para penegak hukum sebab kejahatannya direncanakan, maka ia pasti akan melakukan mitigasi, seluruh kemungkinan itu sudah diantisipasi. Dalam hal ini penegak hukum juga dirasa perlu melakukan investigasi diluar persidangan untuk berusaha mengumpulkan bukti-bukti dimana dalam persidangan ada indikasi-indikasi perbuatannya yang dirasa belum mencukupi. Jika dengan enggunakan hukum normatif yang tidak tegas, ini akan terulang kembali, tidak dapat membuktikan dan menghukum pelaku. Satu sisi semua pejabat memperhatikan hal tersebut sebagai suatu ancaman terhadap integritas nya dan membuat dia

\footnotetext{
${ }^{25}$ Putusan Pengadilan Tinggi Sumatera Utara Nomor
} : 144/Pid/1983/PT-Mdn. terperosok, kehidupan kita yang harus bisa lebih terarah. Karena meski barangkali tidak berniat begitu, logika nya seperti bermain bola, jika wasit mengatakan hansball maka harus siap menerima hukuman. Kesadaran baru harus dibentuk, meski tak sengaja memegang bola maka ada konsekuensi dalam permainan, begitulah yang perlu dilakukan penyelenggara negara.

Dari kedua metode penafsiran tersebut hakim dapat dengan bebas menggunakan metode untuk memahami ketentuan hukum yang ada. Keahlian hakim di dalam menggali dan memahami bagaimana maksud undangundang telah sesuai dengan pasal 28 ayat (1) Undang-undang Nomor 4 Tahun 2004 yang menggariskan "Hakim wajib menggali, mengikuti, dan memahami nilai-nilai hukum dan rasa keadilan yang hidup di dalam masyarakat".

Sebagaimana karena hakim harus memeriksa, dan mengadili perkara yang dihadapkan kepadanya maka ia harus dapat menemukan hukumnya agar perkara tersebut dapat diadili. Disinilah peran teori hukum progresif oleh Satjipto Raharjo, dalam konteks ini hakim dapat dikatakan membentuk hukum apabila pada akhirnya ia dapat menyelesaikan tugasnya dengan baik, yang berarti ia dapat memberikan keputusan yang adil terhadap perkara yang ditanganinya, sebab hakim tidak boleh menolak perkara maka hal ini dibenarkan meski hanya karena tidak ada pengaturan hukum nya. Dengan demikian, dalam melaksanakan amanat tersebut hakim dengan putusanputusannya dapat menjadi suatu alternatif bagi pembentukan hukum dimasa-masa yang akan datang yang harus dihormati setinggi-tingginya. Pembentukan hukum melalui putusanputusan hakim merupakan pembentukan hukum in concreto yang akan lebih dapat memahami nilai-nilai hukum yang hidup di masyarakat. Karena suatu saat pasti akan ada kasus yang terang 
benderang terbukti ada seseorang yang diberi pelayanan seksual maka harus dapat dipidana.

Hal ini selaras dengan pendapat Anton F.Susanto yang dikutip oleh Hernold Ferry Makawimbang yang mengatakan bahwa dalam hukum progresif menjalankan hukum bukan hanya dengan rasio dan silogisme, melainkan juga dengan kepedulian (compassion), ikut merasakan (empathy), kejujuran (sincerity), dan keberanian (dare) ${ }^{26}$ Maka dari itu perlu nya pembahasan gratifikasi ini berlanjut atau sebagai diskursus pada bentukbentuk pemberiannya yang perlu pendalaman. Undang-Undang Pemberantasan Tindak Pidana Korupsi di Indonesia dapat di modifikasi dengan khasanah hukum Islam yang nantinya akan menjadi perbaikan hukum di Indonesia. Dan ketika perihal gratifikasi seks dapat diungkap, maka akan menjadi rujukan tunggal dan perdana bagi institusi penegak hukum. Masyarakat pun akan menyambut dengan baik respon atas penegakan kasus yang sedemikian rusaknya gambaran moral para elit di Indonesia.

Gratifikasi termasuk ke dalam perbuatan risywah yang mana menurut penulis risywah melibatkan tiga unsur utama, yakni pemberi, penerima, dan obyek pemberian. Dalam hukum islam maupun hukum indonesia sama-sama mengaturnya bahwa hal tersebut asalnya diperbolehkan, namun menjadi sesuatu yang dilarang bila digunakan untuk tujuan yang bertentangan dengan hukum, dalam situasi seperti sekarang ini, memang harus diakui sulitnya membedakan mana hadiah dan gratifikasi yang ada tendensinya dengan yang murni sebagai ucapan terima kasih tanpa ada tendensi apa-apa, hal ini akan menjadi bahaya dan mendorong lajunya

\footnotetext{
26 Hernold Ferry Makawimbang, Kerugian Keuangan

Negara Dalam Tindak Pidana Korupsi,

Suatu Pendekatan Hukum Progresif, Thafa Media,

Yogyakarta, 2014, hlm. 315.
}

korupsi yang dapat mengancam profesionalitas, menurunkan standar kualitas, bahkan sampai mempengaruhi keputusan seseorang.

Pengkajian kembali Undangundang Pemberantasan Tindak Pidana Korupsi saat ini diperlukan untuk berani mengabsorsi hukum islam ke dalam hukum positif dalam upaya pencegahan gratifikasi seks. Pada dasarnya tujuan pemberian sanksi hukum menurut pidana islam adalah pencegahan, pengajaran dan pendidikan yang dimaksudkan agar pelaku tindak pidana dapat mengambil hikmah terhadap apa yang didapat pelaku kejahatan ketika mendapat hukuman.

Gratifikasi seksual mempunyai dampak yang lebih besar, karena juga berkaitan dengan moralitas, di samping bisa merobohkan ketahanan negara baik struktur politik, sosial, budaya, ekonomi bahkan keutuhan negara itu sendiri. Selain itu Islam di dalam memberikan putusan hukuman melihat tujuan syariat itu sendiri yang kemudian menjadi tujuan hukum yang disesuaikan dengan kondisi sosial, budaya, dan politik masa itu dan akan terus berkembang. ${ }^{27}$

Maka dari itu penulis berpendapat bahwa sisi ideal nya secara eksplisit pengaturan mengenai gratifikasi seks perlu disebutkan, mengingat pembuktiannya pun berbeda dengan jenis pemberian lainnya, supaya lebih jelas maka perlu adanya revisi. Bagaimana membuktikannya?. Penulis lebih setuju membunyikan unsurnya secara langsung dan memberikan secara tegas cara-cara pembuktiannya, Jadi usulan solusi yang progresif menurut penulis, sebagai penegak hukum tidak ada macam-macam penafsiran jika rambu-rambu nya jelas dan sama cara pembuktiannya. Sejalan dengan asas Lex Scripta, yakni hukum akan bisa mengudara ketika sudah dituliskan

\footnotetext{
${ }^{27}$ H.M. Nurul Irfan, Gratifikasi dan Kriminalitas Seksual dalam Hukum Pidana Islam, Amzah, 2014, hlm. 32.
} 
secara jelas berdasarkan kaidah hukum yang berlaku di Indonesia. Disinilah sisi responsifnya.

\section{F. Kesimpulan}

1. Analisis hukum terhadap gratifikasi seks pada Putusan Pengadilan Nomor: 87/PID.SUS/TPK/2013/PN.BDG tidak terungkap adanya praktek gratifikasi seks yang dinikmati oleh terdakwa. penyidik, juga jaksa penuntut umum tidak memasukkan gratifikasi seks sebagai salah satu unsur tindak pidana korupsi. Penyidik dan jaksa penuntut umum saat itu tidak dapat mengumpulkan bukti-bukti materiil yang menguatkan perbuatan pidana tersebut, sehingga implikasi pada hakim tidak bisa memberikan pertimbangan hukum beserta amar putusannya di pengadilan, namun telah ditemukan nya dugaan gratifikasi seks. Penegak hukum dalam hal ini Hakim sejatinya dapat saja menguraikan perbuatan tersebut dengan cara mengejar sejauh mana saksi Toto Hutagalung sebagai perantara memberikan keterangan nya, diikuti dengan pengumpulan alat-alat bukti lainnya juga dapat melakukan berbagai interpretasi hukum pada putusan pengadilan. Terdakwa secara sah dan meyakinkan melanggar pasal 12 c UU PTPK dan pasal 6 ayat (1) huruf a sesuai dakwaan primer kesatu; pasal 6 ayat (2) huruf a sesuai dakwaan primer kedua; dan pasal 5 ayat (1) UU No 31/1999 sebagaimana yang diubah dengan UU No 20/2001 tentang
Pemberantasan Tindak Pidana Korupsi jo pasal 64 ayat (1) jo pasal 55 ayat (1) kesatu KUHPidana.

2. Analisis pendekatan undang-undang Pemberantasan Tindak Pidana Korupsi dengan hukum islam terhadap gratifikasi seks sebagai upaya pencegahan dalam Pembaharuan Hukum di Indonesia menjadi sangat diperlukan untuk melakukan analisis perbandingan hukum terhadap Undangundang No. 20 Tahun 2001 jo Undangundang Nomor 31 Tahun 1999 tentang Pemberantasan Tindak Pidana Korupsi, karena dalam hukum positif saat ini terkait tindak pidana gratifikasi seksual ketika hanya dengan memakai hukum positif yang ada dalam peraturan perundang-undangan saja, akan mengalami kebuntuan kembali. Mengingat hukum islam lebih memberikan bentuk pemidanaan yang lebih baik dengan mengkategorikan perbuatan seks yang dilarang sebagai jarimah ta'zir. Penguatan sendi-sendi kehidupan dalam pemerintahan dengan melakukan pendekatan religius, sehingga norma agama menjadi bonderis untuk mencegah gratifikasi bentuk apapun khususnya seksual. Sehingga secara normatif dapat diperbaharui peraturan perundang-undangan nya. 


\section{DAFTAR PUSTAKA}

\section{Buku-buku}

Abdul Aziz Dahlan, Ensiklopedi Hukum Islam, Jilid 6, Ichtiar Baru Van Hoeven, Jakarta, 1996.

Ahmad Wardi Muslich, Hukum Pidana Islam, Sinar Grafika, Jakarta, 2009.

Anton M. Moeliono, et al, Kamus Besar Bahasa Indonesia, Balai Pustaka, Jakarta, 2008.

Fence M. Wantu, et al, Psikologi Anti Korupsi, Pustaka Pelajar, Yogyakarta, 2012.

H.M. Nurul Irfan, Gratifikasi dan Kriminalitas Seksual dalam Hukum Pidana Islam, Amzah, Jakarta, 2014.

Hernold Ferry Makawimbang, Kerugian Keuangan Negara Dalam Tindak Pidana Korupsi, Suatu Pendekatan Hukum Progresif, Thafa Media, Yogyakarta, 2014.

Michel Foucault, Ingin Tahu Sejarah Seksualitas, Yayasan Obor Indonesia, Jakarta, 2008.

Musdah Mulia, Mengupas Seksualitas, Opus Press, Jakarta, 2015.

Susan Rose-Ackerman, Korupsi dan Pemerintahan : Sebab, akibat dan Reformasi, Pustaka Sinar Harapan, Jakarta, 2010.

Tjandra Sridjaja Pradjonggo, Sifat Melawan Hukum dalam Tindak Pidana Korupsi, Indonesia Lawyer Club, Surabaya, 2010.

Widyo Pramono, Pemberantasan Korupsi dan Pidana Lainnya : Sebuah Perspektif Jaksa \& Guru Besar, Kompas Media, Jakarta, 2017.

\section{Perundang-undangan}

Undang-undang Dasar Republik Indonesia Tahun 1945.

Kitab Undang-Undang Hukum Pidana

Undang-Undang Nomor 8 Tahun 1981 tentang Kitab Undang-Undang Hukum Acara Pidana

Undang-undang Nomor 20 Tahun 2001 jo Undang-undang Nomor 31 Tahun 1999 tentang Pemberantasan Tindak Pidana Korupsi.

Undang-Undang Nomor 48 Tahun 2009 tentang Kekuasaan Kehakiman.

Keputusan Presiden Nomor 10 Tahun 1974 jo Undang-undang Nomor 47 Tahun 1992 tentang Beberapa Pembatasan Kegiatan Pegawai Negeri Dalam Rangka Pendayagunaan Aparatur Negara dan Kesederhanaan Hidup.

\section{Jurnal dan Makalah}

Direktorat Gratifikasi Komisi Pemberantasan Korupsi

Henry Arianto, Hukum Responsif dan Penegakan Hukum Di Indonesia, Lex Jurnalica Volume 7 Nomor 2, April 2010.

Kade Richa Mulyawati, TESIS : Kebijakan Hukum Terhadap Gratifikasi Seksual dalam Tindak Pidana Korupsi di Indonesia, Universitas Udayana, Denpasar, 2014.

Nur Mauliddar, Mohd. Din, Yanis Rinaldi, Gratifikasi sebagai Tindak Pidana Korupsi terkait Adanya Laporan Penerima Gratifikasi, Kanun Jurnal Ilmu Hukum, Vol.19, No.1, April 2017. 


\section{Internet}

www.trasparency.org/cpi2017

www.kpk.go.id

http://www.tempo.co/read/news/2013

http://jamalwiwoho.com/wp-content/uploads/2013/02/gratifikasi-sex.pdf

http://www.referensimakalah.com/2012/11/definisi-seks-dan-seksualitas.html

Skripsi Jajat Hidayat F SH.http://repository.uinjkt.ac.id 